\title{
The Economics and Empirics of Tax Competition: A Survey and Lessons for the EU
}

\author{
Thushyanthan Baskaran \& Mariana Lopes da Fonseca*
}

\begin{abstract}
We survey the theoretical and empirical literature on local and international tax competition in Economics. On the basis of this survey, we discuss whether EU countries should harmonise tax policies to prevent a race to the bottom. Much of the evidence suggests that tax competition does not lead to significant reductions in tax revenues. Therefore, we conclude that tax coordination is in all likelihood unnecessary to prevent inefficiently low levels of taxation in the EU. But since the evidence against the adverse effects of tax competition is not unambiguous, we also discuss whether intergovernmental transfers might be a less invasive means than outright tax harmonisation to prevent a race to the bottom.
\end{abstract}

Keywords: tax competition, tax coordination, European Union, fiscal federalism

\section{Introduction}

One of the professed goals of the European Union (EU) is to create an ever closer union. In the last few decades, European governments have made considerable progress in pursuing this goal. They have established a free trade zone, a common currency and harmonised educational and vocational standards. One area, however, where harmonisation is markedly absent is tax policy. The lack of harmonisation is not due to inaction by European institutions. The EU Commission, for example, has launched several initiatives for tax coordination over the years, the most recent one being the establishment of an EU-level Tax Policy Group. ${ }^{1}$ Yet, member states remain reluctant to let go of their tax autonomy. ${ }^{2}$ Given the budgetary difficulties in many EU member states, it stands to reason that European policymakers will finally make a serious push towards more tax coordination in the near future. Timid steps have already

\footnotetext{
University of Goettingen, Germany. University of Goettingen, Germany . See e.g. <http:// ec .europa .eu/ commission_ 2010 -2014/ semeta/ headlines/news/2011/01/201101192_en.htm> (last visited 4 December 2013).

2. G. Nicodeme, 'Corporate Tax Competition and Coordination in the European Union: What Do We Do? Where Do We Stand?', MPRA Working Paper 2006:107.
}

been taken, such as the EU Commission's proposal for a Common Consolidated Corporate Tax Base (CCCTB), which is intended to facilitate the harmonisation of tax bases. ${ }^{3}$ One of the rationales cited by the proponents of increased coordination is that national tax autonomy causes harmful tax competition and a race to the bottom. Indeed, if tax competition constrains the ability of governments to raise revenues, part of the solution to the recent budgetary problems may appear to lie in more coordinated tax policies.

The question is whether tax competition really represents such a severe constraint as to necessitate supranational intervention. Are European governments unable to raise sufficient revenues because they have to fear crumbling tax bases? Is tax competition constraining all countries equally or only countries that share certain characteristics? Are there no policies other than outright coordination that could limit incentives to engage in tax competition while allowing national governments to retain a significant portion of their tax autonomy?

Answering such questions based on descriptive evidence alone is difficult. Figure 1 presents the evolution of top marginal personal income tax rates in 23 high-income OECD countries from 2000 until 2013. ${ }^{4}$ Experiences vary both between countries and over time. Until the outbreak of the financial crisis in 2007, top marginal tax rates appear to have, on average, declined. However, there is a considerable heterogeneity. While the decline was pronounced in, for example, Norway and Germany, top marginal tax rates remained stable or even increased slightly in countries such as Japan and Sweden. After the outbreak of the financial crisis, top marginal tax rates appear to have increased in general. However, developments again varied between countries: in New Zealand, for example, top marginal tax rates decreased.

The development of corporate tax rates in OECD countries is similarly ambiguous. Figure 2 presents the development of the combined (subnational and central) statutory corporate tax rates. While there is in general a declining trend, corporate tax rates have basically

3. See e.g. <http:// ec .europa .eu/taxation_customs/taxation/ company tax/common_tax_base/A\#cctb> (last visited 4 December 2013).

4. The data on tax rates was obtained from the OECD's Tax Database at <http://www.oecd.org/tax/tax-policy/tax-database.htm> (last visited 4 December 2013). 


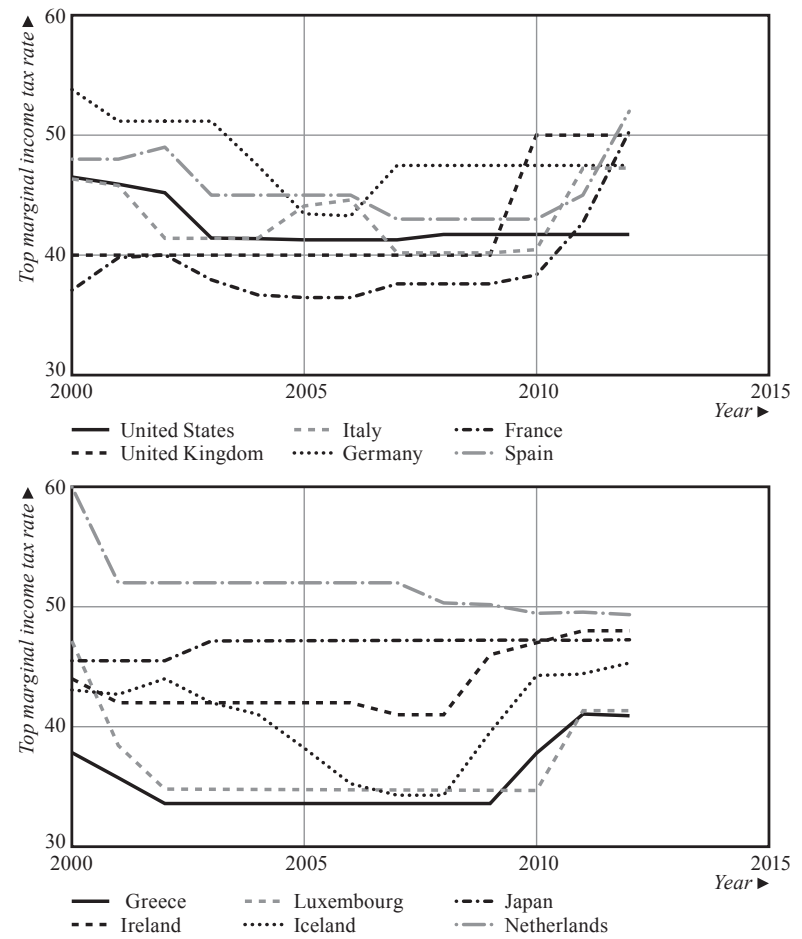

remained stable in countries such as the United States or Japan or, after the financial crisis, even slightly increased in countries such as Iceland or Portugal.

Without a theoretical framework and appropriate empirical methodologies, it is difficult to interpret the descriptive evidence with respect to whether tax competition leads to a race to the bottom in tax rates. ${ }^{5}$ Therefore, this article surveys the theoretical and empirical literature on tax competition in the field of Economics. The theoretical literature was initially confined to local taxation, presumably because international tax competition was not an urgent issue before the acceleration of globalisation during the 80 s and 90 s of the last century. But recently, a sizeable literature specifically concerned with cross-country tax competition has evolved. Mirroring theoretical developments, the empirical literature too was initially focused on local taxation, but has expanded to the international domain with the availability of appropriate data sets.

While the literature on tax competition has come a long way, there still remain unfortunate trade-offs. Tax competition can take place along many dimensions, but the requirements of formal modelling and issues of data availability force researchers to limit themselves to only

5. Another issue that has been discussed in the tax competition literature is whether globalisation causes a convergence of tax rates, but not necessarily to an inefficiently low level. See e.g. J. Slemrod, 'Are Corporate Tax Rates, or Countries, Converging?', 88 Journal of Public Economics 1169 (2004); U. Wagschal, 'Laender unter Anpassungsdruck? Der Internationale Steuerwettbewerb: Ursachen, Wirkungen und Reaktionen Gesellschaft', 55 Wirtschaft und Politik 499 (2006); and W.N. Brooks and T. Hwong, 'Tax Levels, Structures, and Reforms: Convergence or Persistence', 11 Theoretical Inquiries in Law, Comparative Tax Law and Culture 791 (2010). We largely neglect this particular issue in this survey.
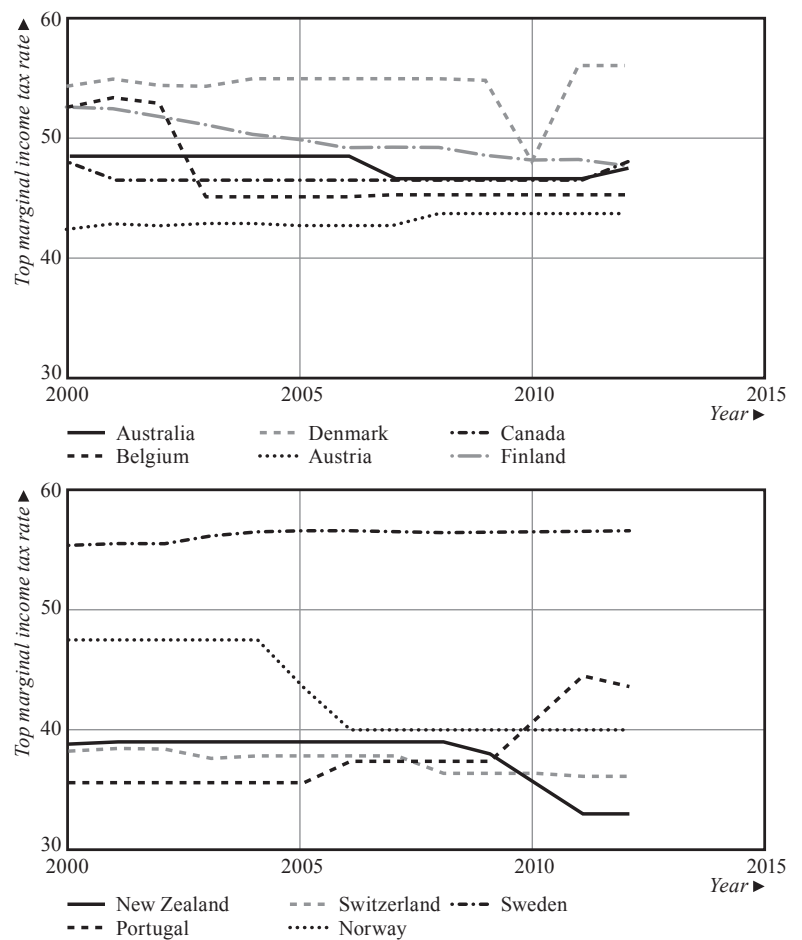

a few decisive features of a country's tax system. We discuss in this article the advantages of the methodological choices usually made in Economics and the disadvantages that the associated simplifications and generalisations entail. We then proceed to a discussion of the conclusions advanced by the theoretical and the empirical literature and a description of the current consensus. Finally, we discuss whether the results in the literature imply that there is a need for further tax coordination in the EU.

This article adds to a large array of existing surveys on tax competition. ${ }^{6}$ The distinguishing features of our survey are (i) an informal and intuitive summary of the theoretical and empirical literature, (ii) a description of the evidence both at the local and international levels and (iii) a discussion of the implications of the existing literature for tax harmonisation in the EU. While many surveys have dealt with each of these issues separately, one of our main contributions is to discuss them in a unified framework and with a unique focus. For example, Keen and Konrad (2012) emphasise theoretical

6. See e.g. J.D. Wilson, 'Theories of Tax Competition', 52 National Tax Journal 269 (1999); T.A. Gresik, 'The Taxing Task of Taxing Transnationals' 39 Journal of Economic Literature 800 (2001); G.R. Zodrow, 'Tax Competition and Tax Coordination in the EU', 10 International Tax and Public Finance 651 (2003); J.D. Wilson and D. Wildasin, 'Capital Tax Competition: Bane or Boon?', 88 Journal of Public Economics 1065 (2004); G.R. Zodrow, 'Capital Mobility and Tax Competition', 63 National Tax Journal 865 (2010); H. Bloechliger and J. Pinero-Campos, 'Tax Competition between Sub-Central Governments', OECD Economics Department Working Paper 2011:872; P. Genschel and P. Schwarz, 'Tax Competition: A Literature Review', 9 Socio-Economic Review 339 (2011); M. Leibrecht and C. Hochgatterer, 'Tax Competition as a Cause of Falling Corporate Income Tax Rates: A Survey of Empirical Literature', 26 Journal of Economic Surveys 616 (2012); and M. Keen and K. Konrad, 'The Theory of International Tax Competition and Coordination', Max Planck Institute for Tax Law and Public Finance Working Paper 2012:6. 


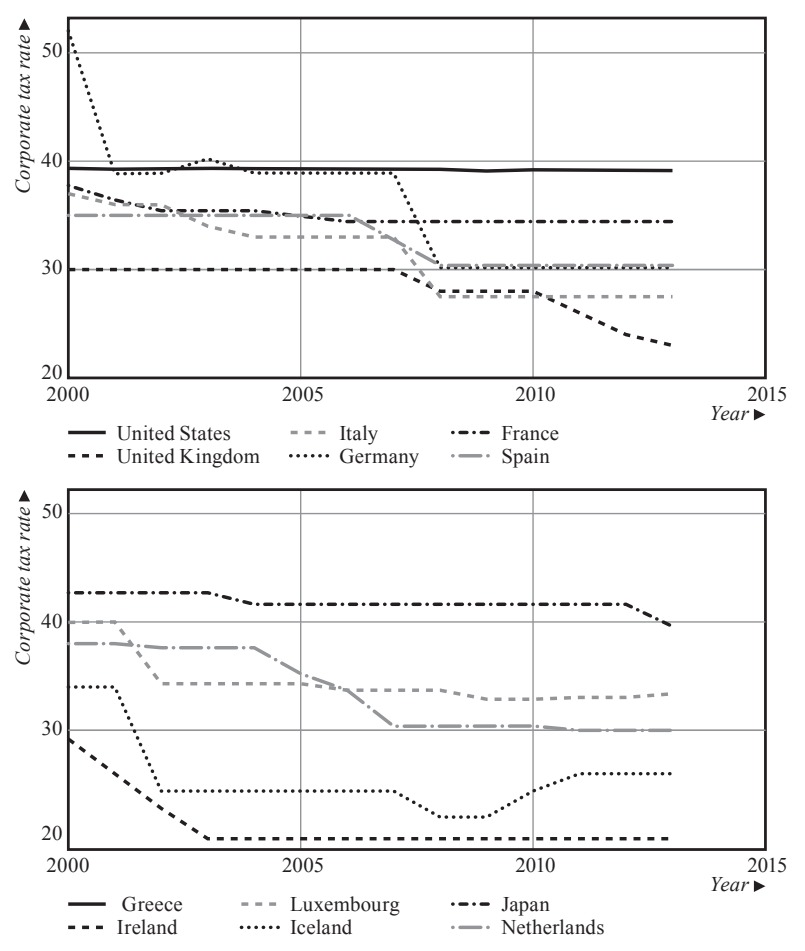

results but are less detailed with respect to the empirical evidence. ${ }^{7}$ Similarly, Genschel and Schwarz (2011) discuss international competition in different types of taxes, but neglect issues related to local taxation. ${ }^{8} \mathrm{~A}$ unified discussion and a unique focus, however, are not the only contributions of our survey. We also cover several recent studies on tax competition that have not yet been considered in previous surveys and that, as we will see, lead to a re-evaluation of the need for tax harmonisation in the EU.

\section{The Theory of Tax Competition}

The first articles dealing with the consequences of uncoordinated tax policies by different political jurisdictions emerged in the context of the economic analysis of local fiscal policy. Tiebout (1956) argues that tax autonomy allows local governments to offer citizens different tax and expenditure bundles. ${ }^{9}$ As citizens can sort themselves across jurisdictions, tax competition leads to an efficient outcome where different preferences of citizens regarding public expenditure are translated into distinct tax rates. Tax competition in this framework has therefore a desirable normative connotation. Subsequent contributions have adapted the Tiebout model, which was originally conceived with respect to households, to

Keen and Konrad, above n. 6.

Genschel and Schwarz, above n. 6.

C. Tiebout, 'A Pure Theory of Local Expenditures', 64 Journal of Political Economy 416 (1956).

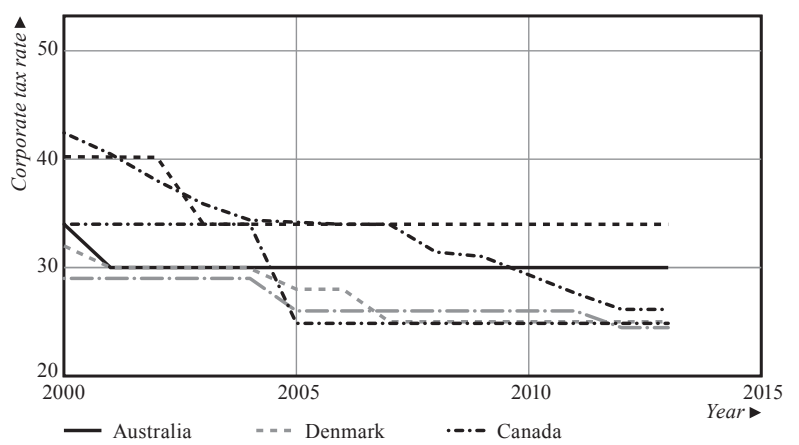

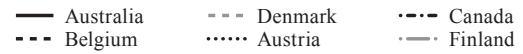

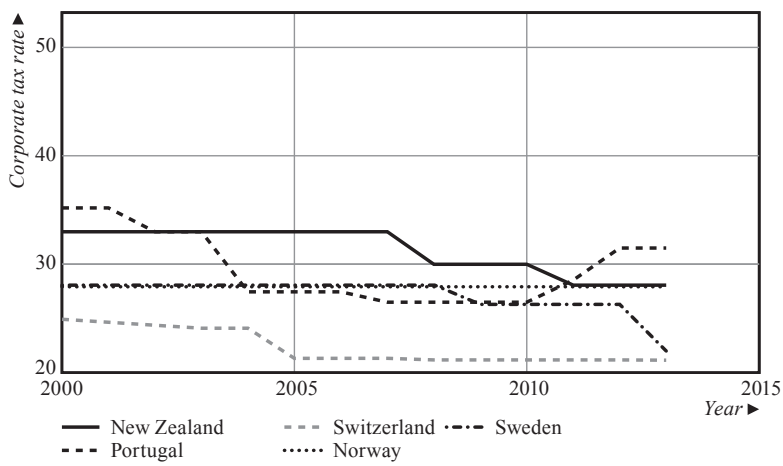

mobile firms. ${ }^{10}$ The results in these papers mirror those of the original Tiebout model.

The modern literature on tax competition, however, puts relatively little emphasis on the voting with one's feet rationale that underlies Tiebout's model. Recent contributions instead advance the idea that political jurisdictions try to poach tax bases away from one another by offering a lighter tax burden. This idea was initially formulated by Bradford and Oates (1971) and Oates (1972), albeit in an informal manner. ${ }^{11}$ These authors argue that jurisdictions engaging in tax competition end up providing too few public goods: to attract mobile production factors, they set lower than optimal tax rates.

It is, however, unclear whether a reduction in the size of the public sector due to tax competition is necessarily bad. The conclusion that lower tax rates as a result of tax competition are harmful relies on the assumption that governments set their tax policy in order to maximise the welfare of their citizens. This assumption is questioned by the Public Choice tradition. Brennan and Buchanan (1980), in particular, argue that governments are Leviathans whose primary interest is to maximise tax revenues as such: governments do not tax to provide essential public goods but because higher tax revenues enhance, for example, the power and prestige of government officials. ${ }^{12}$

10. See e.g. M.J. White, 'Firm Location in a Zoned Metropolitan Area', in W. Oates and E. Mills (eds.), Fiscal Zoning and Land Use Controls (1975).

11. D. Bradford and W. Oates, 'The Analysis of Revenue Sharing in a New Approach to Collective Fiscal Decisions', 85 Quarterly Journal of Economics 416 (1971); and W. Oates, Fiscal Federalism (1972).

12. G. Brennan and J. Buchanan, The Power to Tax: Analytical Foundations of a Fiscal Constitution (1980) 
Despite the long-standing debate around the two conflicting views on the normative implications of tax competition, a formal treatment emerged only in the late 1980s. The seminal papers by Wilson (1986) and Zodrow and Mieszkowski (1986) (from now on referred to as WZM model) adhere to the notion of benevolent governments. ${ }^{13}$ Mirroring the informal literature, these models predict a shift of taxes from mobile capital to immobile factors of production and hence a race to the bottom in the taxation of mobile factors.

The mechanism is as follows. The revenue loss of a tax rate cut for an individual jurisdiction is smaller than the revenue loss for the country as a whole because part of the decline in revenues in the tax-cutting jurisdiction is compensated by mobile factors migrating into it. This inward migration increases the size of the base in the tax-cutting jurisdiction, but this increase comes at the expense of all other jurisdictions. The choice of tax rate thus involves a fundamental trade-off. High tax rates on mobile factors lead, on the one hand, to higher revenues for a given tax base. On the other hand, high tax rates drive away some of the tax base into other jurisdictions. The net effect of an increase in the rate is thus ambiguous: when contemplating tax cuts, local governments have to weigh the rise in revenues because of a larger tax base against a decline because of lower rates. This calculus implies that local governments neglect the externalities of their tax policy: a larger tax base in their jurisdiction implies a smaller one in all other jurisdictions. Thus, the social costs (in terms of lower revenues) of a reduction in tax rates are larger than the individual costs, which leads to inefficiently low tax rates in equilibrium.

Formal models that study the Leviathan hypothesis have been developed by Edwards and Keen (1996) and Rauscher $(1996,1998) .{ }^{14}$ In these frameworks, the aim of every jurisdiction is to maximise its own tax revenues. However, since citizens can emigrate from jurisdictions where the tax burden is too high, tax competition entails, in equilibrium, lower average tax rates throughout the country. Even though these models predict a reduction in the size of government, it is derived that this reduction is - as in the informal literature - beneficial.

Despite the disagreement, the prevailing view remains that tax competition is harmful and leads to suboptimally low tax rates on the mobile production factors. ${ }^{15}$ Consequently, the subsequent literature has extended the WZM model along different lines. One of the extensions was to focus on interregional commodity trade.

13. J.D. Wilson, 'A Theory of Interregional Tax Competition', 19 Journal of Urban Economics 296 (1986); G.R. Zodrow and P. Mieszkowski, 'Pigou, Tiebout, Property Taxation and the Under-provision of Local Public Goods', 19 Journal of Urban Economics 356 (1986).

14. J. Edwards and M. Keen, 'Tax Competition and Leviathan', 40 European Economic Review 113 (1996); M. Rauscher, 'Interjurisdictional Competition and the Efficiency of the Public Sector: The Triumph of the Market over the State?', Kiel Working Paper 1996:732; and M. Rauscher, 'Leviathan and Competition among Jurisdictions: The Case of Benefit Taxation', 44 Journal of Urban Economics 59 (1998).

15. Wilson (1999), above n. 6
Wilson (1987) shows that in such a framework, capital taxation creates an inefficient distribution of public goods and inefficient trade patterns. ${ }^{16}$ Nevertheless, he derives that in contrast to the WZM model, overall public spending must not necessarily be lower than the efficient level.

Another natural extension of the WZM model was to dispense with the assumption that all jurisdictions are the same. By introducing asymmetry into the model, Wilson (1991) and Bucovetsky (1991) study the consequences of tax competition between large and small jurisdictions and show that economic and sociodemographic variables determine whether a particular jurisdiction benefits from competition. ${ }^{17}$ Wilson (1991) derives that small jurisdictions are better off under tax competition than under tax coordination. ${ }^{18}$ Bucovetsky (1991), while obtaining in general similar results, derives in addition that equilibrium tax rates are higher in larger jurisdictions. ${ }^{19}$

Wildasin (1998) changes the focus from the purely competitive model with a large number of jurisdictions to an analysis of only a few local governments. ${ }^{20}$ Consequently, strategic interactions are explicitly studied. ${ }^{21} \mathrm{He}$ shows that if governments use spending as the strategic choice variable and therefore let tax rates adjust residually, then tax rates of different jurisdictions are strategic substitutes. ${ }^{22}$ In this setting, a reduction in tax rates by other jurisdictions causes a given jurisdiction to increase its own tax rate. The rationale is that if a jurisdiction has to maintain a given level of spending, then an outflow of tax bases because of tax cuts in other jurisdictions necessitates the increase of one's own tax rate.

A further strand of the literature on tax competition builds on the so-called New Economic Geography models. $^{23}$ In this framework, certain jurisdictions have agglomeration advantages. Owing to these advantages, firms that settle in these jurisdictions can expect higher profits. Therefore, jurisdictions that offer more agglomeration advantages can afford to levy higher tax rates.

16. J.D. Wilson, 'Trade, Capital Mobility and Tax Competition', 95 Journal of Political Economy 835 (1987).

17. J.D. Wilson, 'Tax Competition with Interregional Differences in Factor Endowments', 21 Regional Science and Urban Economics 423 (1991); and S. Bucovetsky, 'Asymmetric Tax Competition', 20 Journal of Urban Economics 167 (1991).

18. Wilson (1991), above n. 17.

19. Bucovetsky, above n. 17.

20. D. Wildasin, 'Nash Equilibria in Models of Fiscal Competition', 35 Journal of Public Economics 229 (1998).

21. For similar models see e.g. J. Mintz and H. Tulkens, 'Commodity Tax Competition between Member States of a Federation: Equilibrium and Efficiency', 29 Journal of Public Economics 133 (1986); and A. de Combrugghe and $\mathrm{H}$. Tulkens, 'On Pareto Improving Commodity Tax Changes under Fiscal Competition', 41 Journal of Public Economics 335 (1990).

22. In the tax competition context, the statement that tax rates are strategic substitutes implies that if other jurisdictions increase their tax rate for some exogenous reason, a given jurisdiction decreases its tax rate.

23. See e.g. R. Ludema and I. Wooton, 'Economic Geography and the Fiscal Effects of Regional Integration', 52 Journal of International Economics 331 (2000); and R.E. Baldwin and P. Krugman, 'Agglomeration, Integration and Tax Harmonization', 48 European Economic Review 1 (2004). 
Indeed, it can be derived in these models that economic integration may under certain circumstances lead to a race to the top rather than a race to the bottom. ${ }^{24}$

A relatively novel literature analyses how features of the public sector distinct from, yet related to, issues of taxation affect tax competition. An institution that exists in most countries at the local level is a fiscal equalisation scheme. Such a scheme can be structured either vertically or horizontally: either the central government or the other jurisdictions in the same tier of government provide transfers to appropriately defined fiscally weak jurisdictions. The transfers are typically a function of the tax-raising capacity of a given jurisdiction, that is, the value of the tax base. Theoretical contributions such as Fenge and Wrede (2007), ${ }^{25}$ Kelders and Koethenbuerger (2010) and Kotsogiannis (2010) show that incentives to engage in tax competition are lower in the presence of such equalisation schemes. ${ }^{26}$

Although the models reviewed above offer abstract analyses of tax competition that can be applied either to subnational jurisdictions or to sovereign countries, they were originally developed to study local rather than international settings. However, a large theoretical literature has recently developed that specifically models international tax competition. ${ }^{27}$

First, a set of models in this literature integrates both local and international tax competition within a unified framework. For example, Wilson and Janeba (2005) show that decentralisation of tax policy and thus tax competition between subnational governments can serve as a commitment device for the central government in international tax competition and thus improve the welfare of a country as a whole. ${ }^{28}$ Similar contributions are provided by Grazzini and Petretto (2007) and Kessing, Konrad and Kotsogiannis (2009). ${ }^{29}$

Yet many papers that explicitly focus on international tax competition are concerned with how national tax policy as such affects mobile factors. Bjorvatn and Schjelderup (2002) study how tax competition between countries plays out when they provide international

24. For a review of the New Economic Geography literature with a specific focus on tax competition see R. Forslid, 'Tax Competition and Agglomeration: Main Effects and Empirical Implications', 12 Swedish Economic Policy Review 113 (2005).

25. R. Fenge and M. Wrede, 'EU Financing and Regional Policy: Vertical Fiscal Externalities When Capital Is Mobile', 63 FinanzArchiv 457 (2007).

26. C. Kelders and M. Koethenbuerger, 'Tax Incentives in Fiscal Federalism: An Integrated Perspective', 43 Canadian Journal of Economics 683 (2010); and C. Kotsogiannis, 'Federal Tax Competition and the Efficiency Consequences for Local Taxation of Revenue Equalization', 17 International Tax and Public Finance 1 (2010).

27. For a more technical survey than ours, see Keen and Konrad, above n. 6.

28. J.D. Wilson and E. Janeba, 'Decentralization and International Tax Competition', 89 Journal of Public Economics 1211 (2005).

29. L. Grazzini and A. Petretto, 'Tax Competition between Unitary and Federal Countries', 8 Economics of Governance 17 (2007); and S. Kessing, K. Konrad and C. Kotsogiannis, 'Federalism, Weak Institutions and the Competition for Foreign Direct Investments', 16 International Tax and Public Finance 105 (2009). public goods. ${ }^{30}$ Razin and Sadka (1991) study how trade harmonisation is related to international tax competition. ${ }^{31}$ Haufler and Wooton (1999) explore how country size interacts with tax competition. ${ }^{32}$ In the relevant models, the mobile factor is typically interpreted as capital or foreign direct investment (FDI).

A notable aspect of international tax competition is that it can take place over more bases than at the local level. For example, Becker and Fuest (2010) analyse the taxation of profits from international mergers and acquisitions and derive conditions for an optimal tax treatment of such profits. ${ }^{33}$ Fuest (2005) analyses the role of foreign firm ownership for tax competition. ${ }^{34} \mathrm{He}$ derives that taxes may fall with economic integration even if foreign ownership of firms is possible. Fuest, Hunter and Mintz (2005) offer a survey ${ }^{35}$ that discusses various other features and peculiarities of international taxation. ${ }^{36}$ Finally, another strand of the literature on international tax competition is concerned with the consequences of tax coordination. Coordination, if it were possible and costless, would result in the optimal outcome. However, there are various limits to coordination. Peralta and Ypersele (2006) develop a model with asymmetric countries where they derive that in the presence of a common lower bound for tax rates, some countries are better off while others are worse off. ${ }^{37}$ Konrad (2009) shows in a similar framework that minimum taxes might reduce rather than increase equilibrium taxes. ${ }^{38}$ Wang (1999) studies tax coordination in a sequential framework. ${ }^{39} \mathrm{He}$ derives that if tax policy decisions are taken sequentially, then the Stackelberg Leader wins and the Follower loses from tax coordination. Consequently, it is not clear whether tax coordination improves welfare on average.

\section{The Empirical Evidence}

The literature on tax competition at the local level analyses whether there are strategic interactions in tax set-

30. K. Bjorvatn and G. Schjelderup, 'Tax Competition with International Public Goods', 9 International Tax and Public Finance 111 (2002)

31. A. Razin and E. Sadka, 'International Tax Competition and Gains from Tax Harmonization', 37 Economic Letters 69 (1991).

32. A. Haufler and I. Wooton, 'Country Size and Tax Competition for Foreign Direct Investment', 71 Journal of Public Economics 121 (1999).

33. J. Becker and C. Fuest, 'Taxing Foreign Profits with International Mergers and Acquisitions', 51 International Economic Review 171 (2010).

34. C. Fuest, 'Economic Integration and Tax Policy with Endogenous Foreign Firm Ownership', 89 Journal of Public Economics 1823 (2005).

35. C. Fuest, B. Huber and J. Mintz, 'Capital Mobility and Tax Competition', 1 Foundations and Trends in Microeconomics 1 (2005).

36. For example, the implications of residence vs. source based taxation or the role of formula apportionment for transfer pricing have been discussed in the literature. See also Keen and Konrad, above n. 6, and the references therein.

37. S. Peralta and T. Ypersele, 'Coordination of Capital Taxation among Asymmetric Countries', 36 Regional Science and Urban Economics 708 (2006).

38. K. Konrad, 'Non-Binding Minimum Taxes May Foster Tax Competition', 102 Economics Letters 109 (2009).

39. Y.Q. Wang, 'Commodity Taxes under Fiscal Competition: Stackelberg Equilibrium and Optimality', 89 American Economic Review 974 (1999). 
ting behaviour by subnational governments. The idea is that if tax competition exists, then there should be a systematic relationship between the tax choices of a given jurisdiction and those of its neighbours. As the theoretical literature shows, tax rates could be either strategic complements or strategic substitutes. ${ }^{40}$ Similarly, tax competition could lead to either a race to the bottom or to the top. At the outset, therefore, it is not only unclear whether local tax autonomy really entails tax competition, but it is equally uncertain whether tax competition, assuming it exists, will lead to higher or lower equilibrium tax rates.

Yet until recently, the empirical results from the local level were fairly conclusive. The majority of the relevant studies find that tax rates are strategic complements: a decrease in the tax rate by other jurisdictions leads to a decrease in one's own. This, in turn, suggests that tax competition leads to a race to the bottom, at least at the local level. Evidence to this effect has been provided in various settings. Typically, business and property taxes are analysed. An overview of the early empirical literature on local tax competition is offered by Brueckner (2003). ${ }^{41}$

More recent contributions are Buettner (2001), ${ }^{42}$ who explores German municipalities; Brueckner and Saavedra (2001), ${ }^{43}$ who study the Boston metropolitan area; Leprince, Madies and Paty (2007) and Charlot and Paty (2007), who explore French municipalities; ${ }^{44}$ and Feld and Reulier (2009), who study Swiss cantons. ${ }^{45}$ These studies find, in general, evidence for tax competition, and more specifically evidence indicating that tax rates are strategic complements. However, there are results in the literature indicating that tax rates are strategic substitutes: Rork (2003) and Chirinko and Wilson (2011), ${ }^{46}$ for example, find that US states decrease (some) tax rates in response to an increase in rates in other states.

One criticism that has been voiced recently against much of the empirical literature on local tax competition is that the estimates rely on unreasonable identifying

40. Strategic complements are the opposite of strategic substitutes (above n. 22) and imply that if other jurisdictions increase their tax rate for some exogenous reason, a given jurisdiction increases its tax rate too.

41. J. Brueckner, 'Strategic Interaction among Governments: An Overview of Empirical Studies', 26 International Regional Science Review 175 (2003).

42. T. Buettner, 'Local Business Taxation and Competition for Capital: The Choice of the Tax Rate', 31 Regional Science and Urban Economics 215 (2001)

43. J. Brueckner and L. Saavedra, 'Do Local Governments Engage in Strategic Property Tax Competition?', 54 National Tax Journal 231 (2001).

44. M. Leprince, T. Madies and S. Paty, 'Business Tax Interactions among Local Governments: An Empirical Analysis of the French Case', 47 Journal of Regional Science 603 (2007); S. Charlot and S. Paty, 'Market Access Effect and Local Tax Setting: Evidence from French Panel Data', 7 Journal of Economic Geography 1 (2007).

45. L.P. Feld and E. Reulier, 'Strategic Tax Competition in Switzerland: Evidence from a Panel of the Swiss Cantons', 10 German Economic Review 91 (2009).

46. J. Rork, 'Coveting Thy Neighbor's Taxation', 56 National Tax Journal 775 (2003); and R.S. Chirinko and J.D. Wilson, 'Tax Competition among U.S. States: Racing to the Bottom or Riding a Seesaw', CESifo Working Paper 2011:3535. assumptions. ${ }^{47}$ More specifically, the effect of the neighbours' tax policy is typically identified either through functional form assumptions or by using neighbours' characteristics as instruments to induce quasiexogenous variation in neighbouring tax rates. It is unlikely that the functional form assumptions are valid or that neighbours' characteristics are truly exogenous.

A small number of papers use more elaborate identification strategies. Lyytikainen (2012) exploits a reform that increased statutory lower limits in Finland to induce quasi-exogenous variation in local tax rates. ${ }^{48} \mathrm{He}$ finds no evidence for tax competition (and more generally for tax mimicking) in property tax rates. Baskaran (2013) uses a reform to the local fiscal equalisation scheme in a German subfederal state to identify tax competition by municipalities in a neighbouring state. ${ }^{49}$ Again no evidence in favour of tax competition is found. These results contrast the findings based on the standard approach described above, suggesting that the evidence for tax competition in much of the earlier literature might indeed be suspect.

Similarly, Parchet (2012) focuses on Swiss municipalities located close to cantonal borders. ${ }^{50} \mathrm{He}$ uses variation in cantonal-level tax rates in neighbouring cantons to induce quasi-exogenous variation in tax rates in a given municipality. His results suggest once more that standard approaches lead to wrong conclusions. While he finds evidence for tax competition when using the standard methodology with the sign of the estimates indicating that tax rates are strategic complements, once he uses his new methodology, he finds that tax rates are actually strategic substitutes.

The empirical literature on international tax competition is in many ways more complex than the one on local tax competition. One reason for this complexity is that it is difficult to identify an appropriate measure for the tax burden on mobile factors. At the local level, it is relatively easy to measure the tax burden on a specific mobile factor because bases tend to be the same. Second, any further taxes that could affect the decisions of this mobile factor are typically set by higher tiers of government and are therefore the same for all local governments. But at the national level, citizens' and firms' decisions are dependent on various taxes, which vary between countries not only in rates but also with respect to bases.

A second complication is that countries can compete over various mobile tax bases. Theoretical models typically model some abstract mobile production factor that they refer to as capital. But as indicated previously, the mobile factor can assume many forms. It can be under-

47. S. Gibbons and H.G. Overman, 'Mostly Pointless Spatial Econometrics', 52 Journal of Regional Science 172 (2012).

48. T. Lyytikainen, 'Tax Competition among Local Governments: Evidence from a Property Tax Reform in Finland', 96 Journal of Public Economics 584 (2012).

49. T. Baskaran, 'Identifying Local Tax Mimicking: Administrative Borders and a Policy Reform', Center for European Governance and Economic Development Research Discussion Paper 2013:157.

50. B. Parchet, 'Are Local Tax Rates Strategic Complements or Strategic Substitutes?' (Mimeo Universities of Lausanne and Basel 2012). 
stood as financial capital, paper profits, FDI or firms and high-skilled individuals. Each of these factors is subject to different taxes. Identifying a single measure that reflects for each country the tax burden on mobile factors is therefore challenging.

One strand of the literature uses total tax revenues or tax revenues from the corporate and related taxes (e.g. profit taxes) as share of GDP to proxy levels of taxation, ${ }^{51}$ albeit sometimes with sophisticated modifications. ${ }^{52}$ The idea is that tax competition should increase with economic integration. Hence, there should be a negative relationship between economic integration and tax revenues. In general, studies following this approach find no evidence for a decline in tax revenues due to economic integration, and therefore no evidence for harmful tax competition. ${ }^{53}$ Similarly, using a novel method to calculate tax rates on factor incomes, Mendoza and Tezar $(2005)^{54}$ find that tax competition has not triggered a race to the bottom in the $\mathrm{EU}$ with respect to capital taxation. ${ }^{55}$

However, revenue-based measures for tax competition have a number of shortcomings. ${ }^{56}$ First, total tax revenues are endogenous to the tax burden on mobile factors, which can obviously migrate to countries with lower tax rates. Consequently, this measure will tend to underestimate the true tax burden. Second, total tax revenues reflect the burden not only on mobile factors but also on immobile factors. Consequently, tax revenues as share of GDP or similar measures will proxy the true tax burden on mobile factors such as corporations with error. Third, this ratio is a backward-looking measure: it is affected by past tax policies, but does not accurately indicate how future policies will evolve. Mobile factors, however, will be primarily concerned with future developments.

Another strand of the literature, therefore, makes a different compromise. Rather than analysing the full tax burden, these studies focus on a specific mobile factor. The taxation of corporations has received primary atten-

51. D. Swank and S. Steinmo, 'The New Political Economy of Taxation in Advanced Capitalist Democracies', 46 American Journal of Political Science 671 (2002); and G. Garrett and D. Mitchell, 'Globalisation, Government Spending, and Taxation in the OECD', 39 European Journal of Political Research 145 (2001).

52. E.G. Mendoza, A. Razin, and L. Tesar, 'Effective Tax Rates in Macroeconomics: Cross-Country Estimates of Tax Rates on Factor Incomes and Consumption', 34 Journal of Monetary Economics 297 (1994).

53. M.P. Devereux and S. Loretz, 'What Do We Know about Corporate Tax Competition', Oxford University Centre for Business Taxation Working Paper 2012:29

54. E.G. Mendoza and L. Tezar, 'Why Hasn't Tax Competition Triggered a Race to the Bottom? Some Quantitative Lessons from the EU', 52 Journal of Monetary Economics 163 (2005)

55. A related literature studies the effect of globalisation on the welfare state. According to Garrett and Mitchell, above n. 51, the effect of globalisation on the welfare state can either reduce government spending (the efficiency hypothesis) or expand it (compensation hypothesis). For further evidence in support of the compensation hypothesis, which indicates that globalisation leads to higher rather than lower taxation, see also D. Rodrik, 'Why Do More Open Economies Have Bigger Governments?', 106 Journal of Political Economy 997 (1998).

56. M.P. Devereux, R. Griffith and A. Klemm, 'Corporate Income Tax Reforms and International Tax Competition', 17 Economic Policy 449 (2002). tion. Countries have strong incentives to attract corporations by offering lower tax burdens. Corporations not only represent a valuable tax base, they also offer employment to voters. The main aim of this literature is to uncover trends and co-movements in tax rates between different countries and to interpret these trends with respect to international tax competition. Yet while it is possible that corporations are affected by the statutory tax rate, it is problematic that it might not reflect the true tax burden at the national level as definitions of the bases vary between countries. To address this problem, researchers calculate effective tax rates that are distinct from the statutory ones and reflect both bases and rates.

Two types of effective tax rates have been used in the literature. ${ }^{57}$ First, the effective marginal tax rate (EMTR). This measure reflects the increase in the pretax cost of capital of an investment whose post-tax returns just cover the interest rate, that is a marginal investment. More specifically, the difference between pre-tax and post-tax returns divided by pre-tax returns of the marginal investment is defined as the EMTR. Incentives to invest decline with increasing EMTR.

One feature of the EMTR is that only continuous investment decisions - how much to invest - are affected by this tax measure. Discrete choices - whether or not to invest at all - are not accurately captured by the EMTR. When deciding whether to invest at all, mobile factors will not be particularly concerned with the tax burden on a marginal investment but with the average tax burden on the investment as a whole. In order to model such discrete decisions, researchers calculate an alternative measure: the effective average tax rate (EATR). This measure is typically defined as the net present value of all future tax payments divided by the net present value of all future pre-tax returns.

There are several studies that explore trends in statutory or effective tax rates and tax revenues. An early example is the report by the Ruding Committee that investigated capital taxation in the $1980 \mathrm{~s} .{ }^{58}$ This report finds that statutory tax rates have declined in Europe, while bases have become broader. The committee concludes from this pattern that tax competition leads to lower tax rates. Genschel, Kemmerling and Seils (2011) show that statutory corporate tax rates in Europe have declined faster than in the rest of the world since 1990, from which they conclude that corporate tax competition in the EU is stronger than elsewhere. ${ }^{59}$ Similarly, Devereux, Griffith and Klemm (2002) establish for the EU and the G7 countries that effective average corporate tax rates have declined, while marginal tax rates have not changed

57. Devereux, Griffith \& Klemm, above n. 56

58. O. Ruding, 'Report of the Committee of Independent Experts on Company Taxation' [commonly called the Ruding Report], Office for Official Publications of the European Communities (1992).

59. P. Genschel, A. Kemmerling and E. Seils, 'Accelerating Downhill: How the EU Shapes Corporate Tax Competition in the Single Market', 49 Journal of Common Market Studies 585 (2011). 
much in the $1990 \mathrm{~s} .{ }^{60}$ These results, too, provide some evidence for tax competition causing lower tax rates.

While continuing to emphasise forward-looking statutory and effective tax rates, another strand of the literature uses formal econometric techniques to study tax competition instead of looking only at trends and patterns. Benassy-Quere, Fontagne and Lahreche-Revil (2005) analyse the effect of the statutory corporate tax rate on FDI and find evidence for (imperfect) competition in a panel of 11 OECD countries. ${ }^{61}$ Bellack and Leibrecht (2009) provide similar evidence for a panel of Centraland Eastern-European countries. ${ }^{62}$ Wolff (2007) too ${ }^{63}$ finds evidence for a significant effect of taxes on FDI. However, the effect varies for different FDI subcomponents. ${ }^{64}$ Rademacher (2013) compares EMU with nonEMU countries with difference-in-difference regressions. ${ }^{65}$ The results indicate that especially small EMU countries engage in tax competition. More specifically, the author shows that through the course of European integration, effective average tax rates have decreased in small and increased in large EMU countries.

A further strand of the literature attempts to apply the spatial models through which local tax competition is analysed to the international level. The idea is to explore whether tax rates in neighbouring countries affect the rates in a given country. Devereux, Lockwood and Redoano (2008) find in a sample of 21 OECD countries that they compete over corporate tax rates only if their economies are open. ${ }^{66}$ This finding indicates that tax competition does not, in general, diminish revenues at the national level. Using a data set on corporate tax reforms within Europe, Heinemann, Overesch and Rincke (2010) show that countries react to the tax rates of their neighbours. ${ }^{67}$ Egger, Pfaffermayr and Winner (2007), on the other hand, find evidence for strategic interactions in corporate and personal income tax rates

60. Devereux, Griffith \& Klemm, above n. 56

61. A. Benassy-Quere, L. Fontagne and A. Lahreche-Revil, 'How Does FDI React to Corporate Taxation', 12 International Tax and Public Finance 583 (2005).

62. C. Bellak and M. Leibrecht, 'Do Low Corporate Income Tax Rates Attract FDI? Evidence from Central- and East European Countries', 41 Applied Economics 2691 (2009).

63. G.B. Wolff, 'Foreign Direct Investment in the Enlarged EU', 18 Open Economics Review 327 (2007).

64. In addition, see J. Hines, 'Tax Policy and the Activities of Multinational Corporations', in A.J. Auerbach (ed.), Fiscal Policy: Lessons from Economic Research (1997) 401; and J. Hines, 'Tax Sparing and Direct Investment in Developing Countries', NBER Working Paper 1998:6728, for claims that international tax rules have a decisive influence on behaviour of multinational firms, in particular on the location and scope of international business activity.

65. I. Rademacher, 'Tax Competition in the Eurozone: Capital Mobility, Agglomeration, and the Small Country Disadvantage', MPIfG Discussion Paper 2013:13

66. M.P. Devereux, B. Lockwood and M. Redoano, 'Do Countries Compete over Corporate Tax Rates?', 92 Journal of Public Economics 1210 (2008)

67. F. Heinemann, M. Overesch and J. Rincke, 'Rate-Cutting Tax Reforms and Corporate Tax Competition in Europe', 22 Economics \& Politics 498 (2010). in OECD countries. ${ }^{68}$ In a related contribution, Altshuler and Goodspeed (2002) study interactions between European countries and the United States during the period 1968 to $1996 .{ }^{69}$ Their results suggest that competition among European countries in corporate tax rates has decreased over the sample period.

While corporate tax rates are a prominent indicator to measure tax competition, there are a number of alternative instruments that countries employ. Except for official and effective rates, countries can offer corporations and other mobile factors favourable tax treatments and facilitate tax evasion. ${ }^{70}$ Examples include tax holidays, favourable transfer pricing schemes, preferential regimes or opportunities for profit shifting. In the extreme, countries can become tax havens. The incentives and actions along these dimensions are different from those in the standard tax competition framework, but the results are often similar. In equilibrium, countries tend to overprovide favourable tax treatments. There are, however, some notable idiosyncrasies. Johannesen and Zucman (2013), for example, study the effect of G20 countries' compelling tax havens to share bank information during the financial crisis. ${ }^{71}$ They find that this intervention did not lead to a repatriation of funds but rather to a shifting of money to havens that did not comply with the demands of the G20. ${ }^{72}$

Finally, following the theoretical contributions, a relatively recent strand of the empirical literature explores how fiscal equalisation is related to tax policy. Theory and evidence from the local level suggest that certain intergovernmental transfer schemes can be an effective means to limit tax competition. These so-called capacity equalisation schemes typically work as follows. For each jurisdiction, a measure of fiscal need is calculated. Typically, this measure is roughly equal to average local tax revenues per capita. The fiscal need measure is then compared with a measure of fiscal capacity. This second measure is roughly equal to local tax revenues per capita. A share of the difference between fiscal need and fiscal capacity is then compensated by central transfers. Smart (1998) and Koethenbuerger (2002) show theoretically that equilibrium tax rates are higher if such a system of fiscal equalisation is in place. ${ }^{73}$ Empirical evidence from the German state of Lower-Saxony to this effect is offered by Egger, Koethenbuerger and Smart

68. P. Egger, M. Pfaffermayr and H. Winner, 'Competition in Corporate and Personal Income Taxation' (Mimeo Oxford Centre for Business Taxation 2007).

69. R. Altshuler and T.J. Goodspeed, 'Follow the Leader? Evidence on European and U.S. Tax Competition', Rutgers University Department of Economics Departmental Working Paper 2002:26.

70. OECD, Harmful Tax Competition: An Emerging Global Issue (1998).

71. N. Johannesen and G. Zucman, 'The End of Bank Secrecy? An Evaluation of the G20 Tax Haven Crackdown' (Mimeo University of Copenhagen and Paris School of Economics 2013).

72. For a review of the literature on tax havens see D. Dharmapala, 'What Problems and Opportunities Are Created by Tax Havens?', 24 Oxford Review of Economic Policy 661 (2009).

73. M. Smart, 'Taxation and Deadweight Loss in a System of Intergovernmental Transfers', 31 Canadian Journal of Economics 189 (1998); and M. Koethenbuerger, 'Tax Competition and Fiscal Equalization', 70 International Tax and Public Finance 391 (2002). 
(2010). ${ }^{74}$ Similar evidence for the state of Baden-Württemberg is offered by Buettner (2006). ${ }^{75}$

No corresponding evidence is available at the international level as there are no formal international fiscal equalisation schemes yet. However, such an equalisation scheme might become a reality in the EU in the foreseeable future.

\section{Lessons for the European Union}

What do the theoretical and empirical results imply for the future of tax coordination in the EU? The subsidiarity principle, which is enshrined in Article 5 of the EU, states that 'decisions are to be taken as closely as possible to the citizen and that constant checks are made to verify that action at Union level is justified' ${ }^{76}$ Consequently, tax coordination at the EU level should be pursued only if tax competition is truly a problem for public budgets and national-level measures are unable to resolve this problem adequately.

Is tax competition really a problem? Answering this question involves addressing first the positive question of whether tax revenues really suffer because of tax competition. As shown, theoretical predictions are ambiguous and depend on the assumptions that underlie each specific model.

Still, the general consensus is that tax competition constitutes a binding constraint for political jurisdictions and thus causes a race to the bottom. Much of this consensus can be explained by the early empirical papers on tax competition at the local level, which typically found that local tax rates are strategic complements. However, recent papers that employ a credible identification strategy come to different conclusions. In short, there is little evidence for a race to the bottom at the local level.

Empirical studies that explore tax competition at the international level do not indicate that tax competition leads to large revenue losses either. Even if (effective) tax rates seem to have declined in the last few years in European countries, revenues have remained largely stable. ${ }^{77}$

From a positive perspective, therefore, tax competition does not seem to be an urgent problem for European

74. P. Egger, M. Koethenbuerger and M. Smart, 'Do Fiscal Transfers Alleviate Business Tax Competition? Evidence from Germany', 94 Journal of Public Economics 235 (2010).

75. T. Buettner, 'The Incentive Effect of Fiscal Equalization Transfers on Tax Policy', 90 Journal of Public Economics 477 (2006). Further related empirical evidence is available. For evidence with regard to Canada see M. Hayashi and R. Boadway, 'An Empirical Analysis of Intergovernmental Tax Interaction: The Case of Business Income Taxes in Canada', 34 Canadian Journal of Economics, 481 (2001); and M. Smart, 'Raising Taxes through Equalization', 40 Canadian Journal of Economics, 1188 (2007). For evidence with regard to Australia see B. Dahlby and N.A. Warren, 'The Fiscal Incentive Effects of the Australian Equalization System', 79 Economic Record 434 (2003).

76. Art. 5 Treaty on European Union.

77. Devereux and Loretz, above n. 53. countries. But even if tax competition were to lead to revenue losses, it is not obvious how such consequences can be evaluated normatively. Much depends on whether governments are perceived as benevolent or as Leviathans. If governments are reasonably benevolent, the negative features of tax competition will dominate the positive ones. But if they are not, then it is not clear that a race to the bottom is necessarily undesirable. In reality, some governments will conform more to the ideal of benevolence than others. Whether the EU as a whole will benefit from tax coordination is thus unclear for this reason alone.

But even if governments are benevolent and tax competition is truly a threat to public budgets, it can be questioned whether tax coordination is the appropriate answer. First, not all countries will benefit equally from coordination. Theoretical models that allow for asymmetry between political jurisdictions derive - depending on the specific model - that either larger or smaller jurisdictions benefit more from tax coordination. Thus the gains of coordination will be spread unevenly; some jurisdictions might even be worse off. It is not clear why those that will be hurt by tax coordination should support it. ${ }^{78}$ Indeed, that there are losers to tax coordination might be the reason why the EU has hitherto found it difficult to make much progress in this area. Heinemann and Osterloh (2013), for example, show, on the basis of, a survey that several variables determine whether members of the European Parliament support a minimum corporate tax. ${ }^{79}$ While ideology as well as individual characteristics are important, national interests play a role too. In particular, parliamentarians from countries with high corporate taxes support minimum tax rates in the EU.

Second, it can also be questioned whether tax coordination within the $\mathrm{EU}$ is the best way forward if there remains the possibility of tax competition with other regions of the world. Sorensen (2004) attempts to quantify the welfare gains from tax coordination within a group of countries and finds that such gains are modest relative to those that could be obtained if taxes were harmonised worldwide. ${ }^{80}$

Third, some authors argue that European influence over national tax policies is already fairly large. On the basis of a comprehensive analysis of EU tax legislation and ECJ tax jurisprudence, for example, Genschel and Jachtenfuchs (2011) claim that the EU, despite lacking taxing power in the conventional sense, exerts ample regulatory power over national taxation. ${ }^{81}$ In particular, both the VAT and excise taxes are extensively regulated. A further and notably explicit coordination of tax rates

78. V. Dehejia and P. Genschel, 'Tax Competition in the European Union', 27 Politics and Society 403 (1999).

79. F. Heinemann and S. Osterloh, 'The Political Economy of Corporate Tax Harmonisation - Why Do European Politicians (Dis)Like Minimum Tax Rates?', 29 European Journal of Political Economy 18 (2013).

80. P.B. Sorensen, 'International Tax Coordination: Regionalism versus Globalism', 88 Journal of Public Economics 1187 (2004).

81. P. Genschel and $M$. Jachtenfuchs, 'How the European Union Constrains the State: Multilevel Governance of Taxation', 50 European Journal of Political Research 293 (2011) 
would therefore imply that national autonomy over an important policy area will be effectively abolished. This is a strong intervention. In view of the subsidiarity principle, we should ask whether there are weaker instruments to address any adverse effects of tax competition.

Efforts are underway to reshape the EU into a fullfledged fiscal federation. In particular, the introduction of explicit intergovernmental transfers between countries is being discussed. This discussion is being held in view of the current budgetary difficulties in some of the Southern member states. However, intergovernmental transfer schemes can also be a means to address the negative aspects of tax competition in a less invasive way than outright tax harmonisation. As argued above, capacity equalisation schemes provide incentives for jurisdictions to choose higher tax rates voluntarily and thus counteract any race to the bottom.

A reasonable compromise between excessive tax competition and outright harmonisation might hence be the introduction of an intergovernmental transfer scheme. If structured appropriately, a transfer scheme is a milder and more efficient alternative to a centrally coordinated tax policy with no or only little room for national flexibility. As an added advantage, such a transfer scheme would offer the possibility for explicit side-payments between countries and thereby to achieve a mutually beneficial equilibrium. For example, countries that are particularly sceptical of tax coordination could be given either unconditional transfers or they could be offered a higher compensation rate in the equalisation formula.

\section{Conclusion}

In this survey, we summarise the state of the theoretical and empirical literature on tax competition in the field of Economics. We argue that the theoretical predictions are ambiguous. Empirical results are inconclusive as well: early contributions point towards a race to the bottom, while more recent ones reach more differentiated conclusions. On the basis of this evidence, we discuss whether increased tax coordination is a suitable way forward for the EU. Our assessment is that the case for substantial tax coordination in the EU is rather weak.

This assessment, however, does not imply that there is no room at all for tax coordination in the EU. While tax coordination may not be necessary to combat a race to the bottom, some degree of harmonisation in national tax laws will certainly be beneficial. Harmonised tax bases will lower administrative costs and thus benefit both firms and tax administrations. Joint action against tax loopholes and other means to evade taxes will be beneficial as well, both in terms of fostering the rule of law and to garner political support for a well-funded public sector. As long as such benefits to tax coordination exist, the debate about the best way forward will - and should - continue. 